\title{
Cidade e poesia em Lisboa, de Sophia de Mello Breyner Andresen
}

\author{
City and poetry in Lisboa, by Sophia de Mello Breyner Andresen
}

\author{
Daniela Schrickte Stoll ${ }^{1}$ \\ Universidade Federal de Santa Catarina (UFSC), Florianópolis, SC, Brasil.
}

\begin{abstract}
Resumo: este artigo propõe uma análise do poema Lisboa, de Sophia de Mello Breyner Andresen. Partindo de uma abordagem alinhada à crítica literária feminista, pretende-se verificar se outros modelos de leitura corroboram, acrescentam ou contradizem essa primeira aproximação. Para tanto, serão analisados também os sons, as imagens e as ideias colocadas pelo poema, bem como as diferentes interpretações já realizadas por outros/as pesquisadores/as sobre a poeta. Em comparação com um poema escrito por Florbela Espanca a respeito da cidade de Évora, mais de cinquenta anos antes, também será traçada uma análise histórica. Além disso, será discutida a relação entre cidades e poemas ilegíveis - no sentido de se fechar em seus próprios signos ou se abrir para múltiplas formas de interpretação e leitura. Palavras-chave: Cidade. Poesia portuguesa. Modelos de leitura. Sophia de Mello Breyner Andresen.
\end{abstract}

\begin{abstract}
Lisboa, by Sophia de Mello Breyner Andresen. Starting with an approach aligned with the feminist literary criticism, it is sought to verify if other forms of reading corroborate, add to or contradict this first approximation. In order to do that, we will analyze the sounds, images and ideas proposed by the poem, as well as the different ways in which the poet has been interpreted by other researchers. In comparison to a poem written by Florbela Espanca concerning the city of Évora, more than fifty years earlier, a historical analysis will also be elaborated. In addition, the relationship between illegible cities and illegible poems will be discussed - in the sense of closing in on their own signs or opening to multiple forms of interpretation and reading. Keywords: City. Portuguese poetry. Models of reading. Sophia de Mello Breyner Andresen.
\end{abstract}

A poeta portuguesa Sophia de Mello Breyner Andresen (1919-2004) foi a primeira mulher a receber o Prêmio Camões - um dos maiores prêmios literários da língua portuguesa -, e escreveu poesia, contos, artigos, ensaios, histórias infantis e uma peça teatral. Participou ativamente da oposição ao Estado Novo (1933-1974): foi candidata, pela oposição Democrática, nas eleições legislativas de 1968 e candidata à Assembleia Constituinte pelo Partido Socialista, em 1975, após a Revolução dos Cravos. Suas obras abordam temas como as cidades, o exílio, a identidade portuguesa e a relação com o mar. Esses temas aparecem no poema intitulado Lisboa, objeto de análise deste artigo:

\begin{abstract}
Lisboa
Digo:

«Lisboa»

Quando atravesso - vinda do sul - o rio E a cidade a que chego abre-se como se do seu nome nascesse

Abre-se e ergue-se em sua extensão nocturna Em seu longo luzir de azul e rio Em seu corpo amontoado de colinas Vejo-a melhor porque a digo Tudo se mostra melhor porque digo Tudo mostra melhor o seu estar e a sua carência Porque digo Lisboa com seu nome de ser e de não-ser Com seus meandros de espanto insónia e lata E seu secreto rebrilhar de coisa de teatro Seu conivente sorrir de intriga e máscara
\end{abstract}

\footnotetext{
1 Universidade Federal de Santa Catarina (UFSC), Florianópolis, SC, Brasil. Orcid: http://orcid.org/oooo-ooo1-8843-779X. .E-mail: sstolldaniela@gmail.com.
} 
Enquanto o largo mar a Ocidente se dilata

Lisboa oscilando como uma grande barca

Lisboa cruelmente construída ao longo da sua própria ausência

Digo o nome da cidade

- Digo para ver

(ANDRESEN, 2011a, s.p.).

Numa primeira aproximação ao poema, alinhada à crítica literária feminista, percebe-se um ato de enunciação muito evidente: a cidade só pode ser vista, só existe, porque o eu-lírico diz o nome dela. É um gesto muito significativo, porque a cidade deixa de ser o espaço do masculino ${ }^{2}$ para se materializar na enunciação de uma mulher. Pode ser um gesto de apropriação desse espaço (que é público e político), em consonância com a apropriação que as mulheres poetas $^{3}$ do século XX fizeram do espaço literário, igualmente masculino por tradição. Em Lisboa, portanto, percebemos a importância da enunciação e do ponto de vista de um eu-lírico-mulher.

Outro recurso interessante utilizado por Andresen é o de personificar a cidade de Lisboa, que tem um corpo amontoado de colinas. Chama a atenção essa estratégia de personificar a cidade, adotada também pela poeta portuguesa Florbela Espanca (1894-1930), por exemplo, em um poema

2 Em Um teto todo seu (1928), Virginia Woolf (1882-1941) chamou a atenção para a vivência doméstica das escritoras do século XIX (como exemplo ela cita Charlote Brontë, Jane Austen, Emily Brontë e George Eliot), muito diferente da vivência dos homens, que circulavam livremente pelos espaços públicos. As mulheres, segundo Woolf, além de serem desencorajadas a escrever e de não contarem com dinheiro próprio para se sustentar, quando ousavam escrever, tinham suas histórias diminuídas por tratarem de pontos de vista domésticos. No entanto, desde o século XIX, sabe-se qual a percepção dos escritores homens sobre a cidade (Balzac, Dostoiévski, Baudelaire, entre outros). Conforme observou a professora Regina Dalcastagnè, se não vemos mulheres de diferentes classes, raças, idades e orientações sexuais nas representações das cidades, elas se tornam invisíveis: "são apagadas de nossas ruas, praças, prédios públicos - como se nada tivessem a fazer ali, como se nada tivessem a dizer da vida nesses lugares" (DALCASTAGNÈ, 2003, p. 46). No poema aqui apresentado, já do século XX, percebe-se que a poeta não faz nenhuma alusão aos espaços domésticos. Toda a construção do poema ocorre em relação com o espaço urbano.

3 Adota-se o termo poetas, em vez de poetisas, com o intuito de evitar a inferiorização atribuída historicamente ao segundo termo. sobre a cidade de Évora, escrito mais de cinquenta anos antes:

$$
\begin{aligned}
& \text { Évora! Ruas ermas sob os céus } \\
& \text { Cor de violetas roxas ... Ruas frades } \\
& \text { Pedindo em triste penitência a Deus } \\
& \text { Que nos perdoe as míseras vaidades! } \\
& \text { Tenho corrido em vão tantas cidades! } \\
& \text { E só aqui recordo os beijos teus, } \\
& \text { E só aqui eu sinto que são meus } \\
& \text { Os sonhos que sonhei noutras idades! } \\
& \text { Évora!... O teu olhar... o teu perfil... } \\
& \text { Tua boca sinuosa, um mês de Abril, } \\
& \text { Que o coração no peito me almoroça! } \\
& \text {...Em cada viela o vulto dum fantasma ... } \\
& \text { E a minh'alma soturna escuta e pasma... } \\
& \text { E sente-se passar menina e moça... } \\
& \text { (ESPANCA, 2o13, s.p.). }
\end{aligned}
$$

No poema de Espanca, Évora é dotada de um olhar, de um perfil e de uma boca sinuosos - esse trecho contém, sutilmente, um teor erótico, quando o eu-lírico-mulher parece recordar os beijos da cidade-mulher: "E só aqui recordo os beijos teus". As duas poetas, portanto, transformaram as cidades em mulheres, com bocas sinuosas e corpos curvilíneos. $\mathrm{O}$ eu-lírico-mulher, nos dois poemas relaciona-se com a cidade-mulher - reconhece-se nela, apropria-se dela.

O poema de Espanca tem como interlocutora a própria cidade de Évora e é marcado pela subjetividade e pela nostalgia. Em Évora, as ruas são descritas como ermas, podemos vê-las desertas e carregadas de solidão. Se, por um lado, o eu-lírico afirma ter estado em muitas cidades - o que sugere uma liberdade de transitar pelo espaço urbano que muitas mulheres, antes de Florbela, não possuíam -, por outro lado, confere às vielas um aspecto sombrio e fantasmagórico - o que pode remeter ao medo de estar sozinha nesses espaços.

Isso ocorre com o poema de Andresen também: Lisboa é noturna para a poeta, assim como Évora era fantasmagórica para Espanca. Ou seja, ambas recor- 
rem a imagens sombrias para descrever as cidades. Se Espanca utiliza as subjetividades e as lembranças para se inscrever na cidade, Andresen apresenta um teor político ao final do poema: "Lisboa oscilando como uma grande barca / Lisboa cruelmente construída ao longo da sua própria ausência”. A primeira frase retoma a temática das navegações, tão determinante para a construção da identidade de Portugal. A barca que oscila, assim como na peça $O$ que farei com este livro? (1980), de José Saramago (1922-2010), é a metáfora para a dúvida sobre o futuro do país, antes ancorado no imperialismo ultramarino, agora recém-saído da ditadura salazarista. Já a segunda frase é menos explícita, mas pode se referir justamente a esse período ditatorial em que a democracia esteve ausente.

Nota-se, desse modo, que as poetas também utilizam estratégias diferentes: Espanca recorreu às subjetividades e às lembranças, Andresen construiu um gesto de enunciação e de reflexão sociopolítica. Ambas, no entanto, colocaram as mulheres como sujeitos do olhar, do transitar e do enunciar no espaço urbano, ao mesmo tempo em que se inseriram no contexto literário, social e político de suas épocas. Percebe-se, então, que o espaço urbano já não é um espaço interditado para elas e para seus eus-líricos, mas um espaço - ainda que sombrio - do qual se apropriam e sobre o qual elas criam.

Após essa primeira aproximação, partimos para outros modelos de leitura, com o objetivo de verificar se corroboram, acrescentam ou contradizem essa leitura inicial. Para tanto, serão analisados também os sons, as imagens e as ideias colocadas pelo poema, bem como o modo com que o poema Lisboa se insere no contexto histórico e local. Por fim, também será discutida a ideia de legibilidade e ilegibilidade da poesia, com base em A política da sereia (2015), análise de Jacques Rancière sobre a poesia de Stéphane Mallarmé (1842-1898), francês citado pela própria Sophia em reflexão comparativa.

Para uma abordagem histórica, também será interessante pensar a comparação entre os poemas de Andresen e Espanca, escritos com uma diferença de pouco mais de cinquenta anos. Nesse período que as separa, de 1930 a 1983, emergiram teorias do francês
Michel Foucault, associadas a uma virada, no final do século XX, ao pós-estruturalismo: quando se passou a perceber que diversos conceitos, antes tidos como fixos, eram construídos por discursos e estruturas de saber e poder. Esse momento teve também relação com os estudos de Jacques Derrida, francês que trabalhou a desconstrução de estruturas conceituais e linguísticas de oposições binárias até então estanques. As teorias do pós-estruturalismo e a virada linguística parecem ter influência sobre o poema de Andresen, Lisboa, que é todo construído a partir de um gesto de enunciação: "Tudo se mostra melhor porque digo".

Além disso, no período entre os dois poemas, aconteceram também a "revolução sexual" e as diversas outras manifestações sociais ao redor do mundo (as revoltas estudantis, os movimentos contraculturais, as lutas pelos direitos civis, entre outros). Portugal viveu, nesse período, três regimes políticos diferentes - a ditadura militar (1926-1933), o Estado Novo (1933-1974) e a democracia (1974-). No decorrer desses anos, as mulheres conquistaram e perderam vários direitos (em 1967, por exemplo, foi revogado, em Portugal, o Código Civil Napoleônico, que subjugava as mulheres aos maridos e proibia que elas adquirissem ou administrassem bens sem o consentimento deles, entre outras coisas). Notase uma grande diferença na forma como Espanca $e$ Andresen eram vistas pela sociedade. A primeira foi pouco conhecida em vida e enfrentou o preconceito da opinião pública, porque desafiava os costumes da época (além de ter se divorciado duas vezes, sua obra incluía poemas eróticos e poemas que refletiam sobre a identidade da mulher), já a segunda, Andresen, participou ativamente do mundo político e sua escrita foi reconhecida em vida. A própria crítica literária feminista surgiu e se fortaleceu no período entre os dois poemas, nas décadas de 1970 e 1980.

É possível perceber diferenças na forma dos dois poemas também. Enquanto o poema de Espanca é um soneto composto majoritariamente de decassílabos heroicos e de rimas conforme o esquema $\mathrm{ABAB}$ BAAB CCD EED, o poema de Andresen tem versos livres e brancos. A primeira afirmava ter influência de Luís de Camões (também escritor de sonetos, 
porém no século XVI), e a segunda reporta-se a autores como Fernando Pessoa (1888-1935). Ambas escreveram no século XX, quando já vigorava a ideia de que cada autor tem o seu estilo, ao contrário de momentos anteriores, quando a imitação dos bons poetas da Antiguidade era obrigatória e sinônimo de qualidade. Com o romantismo e a emergência do capitalismo/mercado, no século XIX, passou-se a valorizar a originalidade e a liberdade no estilo. Nesse período, também foi grande o enfoque dado ao nacionalismo, por conta da constituição dos Estados-nação, assim como o enfoque dado à ciência, à história e à sociologia.

No século XX, com a modernidade, as escritas sobre cidades tomaram lugar com Baudelaire, com o flanêur que deambulava pelas grandes avenidas recém-abertas em Paris pelo Barão Haussman. Segundo o professor Aleilton Fonseca (2009), a ilegibilidade das cidades modernas tornou-se um desafio para os poetas. Na busca por reinscrever, em imagens e palavras, a cidade "ilegível", também ocorre um gesto de decifração do espaço urbano:

O seu usuário e transeunte têm dificuldade de situar-se nelas, de reconhecê-las, mapeá-las e compreendê-las, tal é o emaranhado de signos que compõem a tessitura de seu território físico e simbólico. A poesia urbana é uma resposta a esse fenômeno da cultura humana moderna e contemporânea (FONSECA, 2009, p. 61).

Isso nos reporta a questões como legibilidade ou ilegibilidade na própria poesia. Se Stéphane Mallarmé, no século XIX, preocupava-se com a restituição de um suposto ritmo essencial da linguagem humana, no interior do poema, e buscava "dar um sentido mais puro às palavras da tribo", Andresen afirmou que buscava "dar um sentido mais justo aos actos da tribo". Ou seja, para ela, a linguagem era um meio de intervir na realidade, conforme expressou em entrevista ao jornal O tempo e o modo, em 1963:

O poeta não vem apenas contar e cantar o mundo. Vem também modificá-lo. Mallarmé dizia que o fim da poesia era "dar um sentido mais puro às palavras da tribo”. Mas eu creio que a poesia vem também dar um sentido mais justo aos actos da tribo. Pois as palavras não estão limitadas a si mesmas. Não é possível purificar as palavras sem purificar também a relação do homem com a realidade. Por isso não distingo entre poesia gratuita e poesia comprometida, pois não há poesia gratuita. Distingo sim entre poesia e esteticismo. Para o esteta a poesia é um ornamento da vida. Para o poeta a poesia é uma forma de salvação sua e dos outros. E esta busca de salvação não pode ser alheia à busca de uma forma concreta e prática de justiça (ANDRESEN, 2011b, s.p.).

Portanto, Andresen pretendia ser legível para que pudesse ser lida por todos (ser justa, segundo sua visão). Para ela, a tarefa do/a escritor/a numa sociedade socialista era lutar para que o acesso à escolarização e aos livros fosse o mais democrático possível, de modo que, segundo a pesquisadora Eloisa Aragão, "pudessem chegar às mãos dos pequenos e ser compreendidos, ao mesmo nível, por filhos de camponeses, de operários, ou de professores universitários" (ARAGÃO, 2014, s.p.). Assim, a poeta se distancia da ilegibilidade atribuída a poetas como Mallarmé. Por outro lado, a época de Andresen era receptora daquilo que autores como Mallarmé introduziram (ou implodiram) em termos de teoria literária. Para o filósofo francês Jacques Rancière (2015), Mallarmé apontou para uma nova época que, com o deslocamento das pompas das religiões e dos reis, dissolveu os mitos de origem e de soberania, as palavras e os discursos. Através da linguagem, Mallarmé evocou esse vazio. O "nada" de Mallarmé tem, para Rancière (2015), relação com o não-ser de Hamlet, ideia também evocada por Andresen no poema, como veremos adiante. Além disso, Mallarmé abriu espaço para o verso livre, empregado por Andresen em Lisboa e em outros poemas. Ele rompeu com as regras métricas (a crise de verso), implodindo-as por dentro, com quebras, vírgulas, continuidades e descontinuidades.

Por outro lado, o objetivo de Mallarmé não era excluir leitores/as, de acordo com Rancière (2015), mas abrir os olhos daqueles que conseguiam lê-lo, 
já que o poeta não oferecia chaves prontas de leitura, mas abria-se para múltiplos sentidos. Assim, o ilegível em Mallarmé não era uma característica negativa, relativa à obscuridade do texto e à exclusão de leitores/as, mas uma característica positiva: uma forma de não se bastar, de não se esgotar em uma única leitura (como acontece com o texto legível), daí a imensa fortuna crítica a seu respeito.

Ainda que Andresen se proponha a ser legível (no sentido de acessível), seu poema também pode ser tido como ilegível (no sentido de se abrir para mais de uma forma de interpretação, não se esgotando numa única leitura, como parecem apontar as análises realizadas neste artigo). Seu poema parece conter mais formas de interpretação do que o poema de Florbela Espanca, por exemplo. Para verificar outras leituras possíveis, além das leituras sociopolítica/ feminista e histórica já esboçadas, acrescento agora uma análise mais minuciosa dos sons, das imagens e das ideias colocados pelo poema.

Em relação aos sons, percebe-se que as vogais mais utilizadas são abertas e que há rimas no final e no interior dos versos (sul / azul; lata / dilata; carência / ausência). Ocorre uma grande repetição dos sons de "r" e "s" em todo o poema. É possível separar as poucas palavras que não têm essas consoantes/sons. Nelas, notam-se outras repetições interessantes, podendo ser agrupadas de acordo com o som predominante (consoante) da última sílaba: (1 - "G") Digo / chego / longo / digo / digo / longo / digo / digo (2 - "D") quando / vinda / amontoado / tudo / (3 - "M") como / nome / nome / como / nome (4 - "T") lata / conivente / enquanto. Ainda seria possível agrupar quando / vinda / conivente / enquanto pelo acento na sílaba com "n”. Todas essas palavras são paroxítonas, conforme percebe-se pela marcação em itálico. Assim, a única palavra que não tem correspondência sonora com nenhuma outra, no poema, é “vejo". Essa exceção pode remeter à ideia central do poema (dizer para ver), de modo que todo o poema é feito de dizer (sons/rimas/repetições), à exceção da única palavra que aponta para o ver.

No que diz respeito às imagens colocadas pelo poema, percebem-se os seguintes grupos: (1 - nave- gações) rio, mar, barca; (2 - obscuridade) máscara, secreto, noturna; (3 - luz) brilho, sorriso, rebrilhar, sorrir, luzir; (4 - personificação) corpo, sorriso, carência, insônia; (5 - grandiosidade) extensão, longo, largo, grande, abre-se, ergue-se, dilata, grande; (6 - ações) digo, vejo, chego; (7 - teatro) ser e não-ser, coisa de teatro, máscara. Logo se conclui que o enfoque principal está na cidade/ambiente exterior, ao contrário do que se percebe no poema de Espanca, que traz mais imagens relacionadas ao eu-lírico e suas subjetividades. Isso pode ser relacionado à proposta de Andresen de representar o real, conforme ela argumentou em sua Arte poética III:

Sempre a poesia foi para mim uma perseguição do real. Um poema foi sempre um círculo traçado à roda duma coisa, um círculo onde o pássaro do real fica preso. E se a minha poesia, tendo partido do ar, do mar e da luz, evoluiu, evoluiu sempre dentro dessa busca atenta. Quem procura uma relação justa com a pedra, com a árvore, com o rio, é necessariamente levado, pelo espírito de verdade que o anima, a procurar uma relação justa com o homem. Aquele que vê o espantoso esplendor do mundo é logicamente levado a ver o espantoso sofrimento do mundo. Aquele que vê o fenómeno quer ver todo o fenómeno. É apenas uma questão de atenção, de sequência e de rigor (ANDRESEN, 2011c, s.p.).

Nos grupos de imagens, percebem-se também oposições, como, por exemplo, entre a obscuridade e o brilho, entre o ser e não-ser, entre o estar e a carência, entre os meandros das ruas e o largo mar que a Ocidente se dilata. As oposições de imagens, assim, percorrem todo o poema e fazem com que consigamos ver melhor. Porque, se a noite e as colinas tornam a cidade obscura/ilegível (é difícil ver mais além), o brilho, a força das contradições e a enunciação da cidade (porque digo) fazem com que ela seja mais visível/legível.

Quanto às ideias apresentadas pelo poema, elas parecem divididas em dois blocos. Na primeira metade, a cidade é descrita em sua espacialidade. No segundo trecho é que surgem ideias, a começar pelo nome de ser e de não-ser. Essa colocação parece estar 
relacionada ao mito de origem do nome da cidade de Lisboa, que teria sido fundada por Ulisses - daí Ulissepona/Lisboa. Esse mito foi também citado pelo português Fernando Pessoa, em Mensagem (1934):

ULISSES / O mytho é o nada que é tudo. / O mesmo sol que abre os céus / É um brilhante e mudo - / O corpo morto de Deus, Vivo e desnudo. / Este, que aqui aportou, / Foi por não ser existindo. / Sem existir nos bastou. / Por não ter vindo foi vindo / E nos criou. / Assim a lenda se escorre / A entrar na realidade, / $\mathrm{E}$ a fecundá-la decorre. / Em baixo, a vida, metade / De nada, morre (PESSOA, 1934, s.p.).

Percebe-se que Pessoa também alude a essas contradições do mito de Ulisses, do nada que é tudo, do foi por não ser (o criador da cidade, a origem do nome), assim como o ser ou não-ser de Andresen: a lenda que não é verdade, mas que, em sua permanência, se tornou verdade. Segundo as pesquisadoras Licia Matos e Ângela Faria (2016), "A poeta se tornou conhecida por verter sobre grande parte de seus versos o encantamento pelo universo helênico, marcando a seu modo uma aproximação entre Portugal e Grécia, duas nações costeiras regidas pelo mar" (MATOS; FARIA, 2016, p. 677). Matos e Faria (2016) estudaram a relação entre a história de Ulisses/ Odisseu $^{4}$ e a dos portugueses, partindo desse mito que aproxima as narrativas coletivas dos dois povos. Segundo elas, “[...] a literatura portuguesa absorveu o herói da Odisseia, tomando-o como personagem de enorme importância para a formação da nação lusitana" (MATOS; FARIA, 2016, p. 677). A lenda não pode ser verídica, uma vez que é inspirada em um personagem mítico e literário, mas se instalou na memória portuguesa:

Esse encanto se confirma nas manifestações artísticas locais, muitas delas, até hoje, fazendo reviver a memória do grego. Na literatura, o herói e os desdobramentos de sua viagem são cantados por referências como Luís de Camões,

4 Odisseu (em grego) ou Ulisses (em latim) foi um personagem da mitologia grega e romana que figurou na Ilíada e na Odisseia, de Homero (séc. IV a.C. - séc. VIII a.C.).
Fernando Pessoa, a já referida Sophia de Mello Breyner Andresen, Miguel Torga, Manuel Alegre, Almeida Faria, entre outros poetas e prosadores (MATOS; FARIA, 2016, p. 679).

Outras explicações para o nome da cidade afirmam que, por volta de 1200 a.C., os fenícios fundaram uma povoação nomeada Alis Ubbo, que significa enseada amena. Na época dos romanos, essa povoação teria sido designada Olissipo Felicitas Júlia. Mais tarde, com as invasões dos visigodos, a cidade se chamou Ulixbona. No século VIII, a mudança seria para Al-Usbuna. Ou seja, todos nomes que, apesar das mudanças, conduzem ao atual Lisboa, o nome de ser e de não-ser, um misto de realidade e mito.

Por outro lado, a ideia de ser e não-ser também remete a Shakespeare e ao teatro, temática que é muito presente no segundo trecho do poema, aludindo a outro fator histórico: a noite de Lisboa, onde se ambienta o poema, esteve muito ligada aos teatros. Segundo o Best guide, guia turístico online,

No início do século XX aos finais dos anos 20 , a noite de Lisboa era indissociável dos seus teatros, do drama à comédia, da opereta (ainda muito popular nessas décadas) ao teatro de revista cujo Parque Mayer abre ao público em 1922 prometendo "um teatro, um carroussel e uma esplanada” (BEST GUIDE, s.d.: s.p.).

Essas alusões ao brilho e às "coisas de teatro" parecem compor a cena que Andresen constrói. Podemos ver a cidade à noite, com seu longo luzir de azul e de rio e seu secreto rebrilhar de coisas de teatro. Parece ser para esta caracterização que se volta a palavra insone: a cidade que, com sua agitada vida noturna, não dorme.

No entanto, a poeta, que tinha forte participação no Partido Socialista e acreditava que a poesia deveria ser comprometida, alude também aos bairros de lata (como são chamadas as favelas em Lisboa), ao conivente sorrir que essa cidade brilhante e insone oferece a outra parte da população. Andresen expõe, portanto, a contradição entre o brilho do teatro e os bairros de lata: a verdadeira Lisboa é feita de tudo isso. Porque, conforme Aragão (2014), a contradi- 
ção da vida social esteve sempre presente na obra de Andresen. A presença do oceano acrescenta ainda a lembrança constante do passado heroico de Portugal - as navegações, que também dão título ao livro em que foi publicado o poema. Então, a Lisboa real que a poeta nos mostra é essa união de brilho de teatro, de favelas e dos grandes feitos do passado. Como uma grande barca, Lisboa oscila entre todas essas contradições, num mar que vai e vem, um mar de ser e não-ser. Oscila com o fim do salazarismo, sem saber ainda qual será seu futuro. É ou não é uma cidade mito? É ou não é brilhante/ iluminada/boemia? É ou não é memória de grandes feitos marítimos? É ou não é grande/vasta/larga/ enorme? O que resta, para além desse não-ser, dessa ausência evocada por Andresen? Torna-se difícil ver a cidade e faz-se necessário que o eu-lírico diga seu nome-mito-barca para ver, para dar um sentido mais justo a essa História.

Em entrevista a Maria Armanda Passos (1982), Andresen expressou essa dificuldade de ver de maneira clara: "É verdade que a política da nossa época é de tal maneira contraditória, de tal maneira cheia de fraudes, de oportunismos, de confusões que, neste momento, não se vê de maneira clara" (ANDRESEN, 2011d, s.p.). Assim, ela conclui que escrever era sua verdadeira participação política. A mesma dificuldade de ver foi expressada em outro poema: "Nada me resta senão olhar de frente / Neste país de dor e incerteza / Aqui eu escolhi permanecer / Onde a visão é dura e mais difícil" (ANDRESEN, 2003 apud ARAGÃO, 2014, s.p.).

Quanto ao gesto de nomear, isso também apareceu em outros momentos da trajetória da poeta, que publicou, em 1977, o livro O nome das coisas, "[...] em que se destacam alguns [poemas] marcados pelo repúdio à demagogia e a desesperança diante do cenário criado após a revolução" (ARAGÃO, 2014, s.p.). Assim, é possível ler o conivente sorrir, a intriga e a máscara como representativos dessa demagogia.

Andresen questionava o uso das palavras para a construção do poder e do capitalismo. A poeta pertencia a um grupo de católicos progressistas contra o regime Salazarista e defendia que a palavra é sagrada:

Com fúria e raiva / Com fúria e raiva acuso o demagogo / E o seu capitalismo das palavras / Pois é preciso saber que a palavra é sagrada / Que de longe muito longe um povo a trouxe / E nela pôs sua alma confiada / De longe muito longe desde o início / O homem soube de si pela palavra / E nomeou a pedra a flor a água / E tudo emergiu porque ele disse / Com fúria e raiva acuso o demagogo / Que se promove à sombra da palavra / E da palavra faz poder e jogo / E transforma as palavras em moeda / Como se fez com o trigo e a terra (ANDRESEN, 2010 apud ARAGÃO, 2014, s.p.).

Neste ponto, podemos analisar outros métodos de leitura possíveis da obra de Andresen, utilizados por críticos e estudantes da obra da poeta. Para a pesquisadora Maria Lúcia Outeiro Fernandes (2014), por exemplo, o interesse de Andresen no ato de nomear tem relação com um

[...] tempo ancestral de unidade e pureza, tempo de criação e de conhecimento, em que o homem era investido de um forte poder de nomear os seres, dando-lhes existência, o que fazia dele um cocriador do universo, ao lado das forças divinas, das quais o homem compartilhava (FERNANDES, 2014, p. 101).

A abordagem de Fernandes (2014), portanto, parte das relações entre mito e poesia. A pesquisadora defende que a palavra, assim como o mito, participa de um ato de criação no momento de sua enunciação. Desse modo, Andresen entrelaça o antigo e o novo a partir da união entre aspectos da forma/linguagem - som, imagem, ritmo, métrica, símbolo, metáfora - e do conteúdo - mítico. Para Fernandes (2014),

As imagens evocadas pelos termos "viagem", "barcos" e "navegação" também são recorrentes [na obra de Andresen] e contam a trajetória primordial do homem, além de pontuarem, muitas vezes, um sonho de regresso e de reconstrução 
da integridade perdida (FERNANDES, 2014, p. 102-103).

Essa visão é corroborada pelo fato de ser possível encontrar alusões a vários mitos nos poemas de Andresen, como os mitos de Níobe, Endymion e Kassandra. Além disso, segundo a pesquisadora, Andresen acreditava que os/ as poetas são aqueles/as que alimentam uma “escuta” visionária do mundo, de modo que

Visão e audição trabalham juntas na recriação do universo. O mundo ressoa dentro dele como imagem e como palavra. Mesmo valorizando o trabalho formal, que resulta em composições elaboradas com visível rigor, Sophia enfatiza que, antes da criação do texto, o poeta necessita ter tido uma vivência de intimidade com o mundo e com os seres, na elaboração silenciosa de uma compreensão mítica do universo. Esta vivência é atualizada na criação do poema. Desse modo, o próprio processo de criação assemelha-se a um ritual onde o mito das origens é revivido (FERNANDES, 2014, p. 108).

Podemos entender, então, o poema Lisboa como uma representação dessa ideia: "digo para ver" como forma de representar a união entre imagem e palavra, visão e audição (como já havíamos concluído na análise dos sons do poema). Além disso, a pesquisadora afirmou que, para Andresen, a cidade é "[...] o espaço degradado, fruto da sucessão de rupturas e quedas sofridas pelo homem em sua trajetória sobre a terra" (FERNANDES, 2014, p. 97). Por essa perspectiva, o poema Lisboa, em vez de abordar as contradições sociais e históricas da cidade, teria maior relação com rupturas e quedas do ser humano em um caráter mais mítico e ancestral, como se a cidade representasse "[...] o espaço do terror, da destruição máxima, do isolamento e da completa degradação do ser humano" (FERNANDES, 2014, p. 97).

Já o pesquisador Durval Muniz de Albuquerque Júnior (2014) analisou a obra de Andresen a partir da relação entre corpo e tempo/saudade/história. Para ele, as imagens empregadas pela poeta guardam relação com a sua própria infância: “Talvez, o fascínio que vai demonstrar ter pelo mar, em toda a sua obra, se deva ao fato de ter ouvido muitas vezes lhe ser contada a saga marítima que trouxe seu bisavô paterno da Dinamarca até Portugal" (ALBUQUERQUE JUNIOR, 2015, p. 11). Ou ainda:
A presença do mar em seus poemas, muitos deles escritos no interior dessa casa [na praia da Granja, onde a família Andresen passava férias], sob a luz branca e clara de suas janelas, se deve a essa vivência infantil, ao lado da família, nos verões à beira do Atlântico, seu mar de eleição (ALBUQUERQUE JUNIOR, 2015, p. 13).

Ou seja, é através de aspectos biográficos da autora que Albuquerque Júnior analisa elementos da poética andresiana. Mesmo as questões sociais, presentes na obra dela, são atribuídas por ele ao contato que Andresen teve, desde a infância, com trabalhadores e criados que frequentavam a casa de sua família rica. Segundo o pesquisador, o afastamento de Andresen de seu "reino protegido", em 1936, quando se deslocou à Lisboa para cursar a faculdade, provocou o estranhamento que ela tem pela cidade:

O encontro com a cidade, com a vida urbana de Lisboa, lhe causa profundo estranhamento, a ponto de abandonar o curso sem concluí-lo, refugiando-se novamente no Porto. [...]. Sua escuta educada pela audição, desde muito pequena, das músicas de Bach, que ouvia no gramofone do escritório do avô, pelo violão que José Ribeiro tocava nas tardes de Granja, pela música de Mahler ouvida em casa de amigos em Matosinhos, teria agora que se adaptar aos fados e canções populares que uivavam no rádio ou nos bares e tavernas de Lisboa. Seu ouvido ansiará pela chegada da noite, quando a redução dos ruídos, o silêncio permitirá que possa escutar a poesia que ressoa em germe no interior de si. Seu fascínio pela noite se amplia, pois é nessa hora de recolhimento, quando a cidade adormece, que nela desperta a sensibilidade poética (ALBUQUERQUE JUNIOR, 2015, p. 22-23).

Nessa explicação podemos encontrar alguns elementos do poema Lisboa, como os contrastes 
e o fascínio pela noite da cidade. Outros pontos levantados pelo pesquisador também nos remetem ao poema:

A cidade é [para Sophia] sobretudo o oposto do mar, o espaço do aperto, da prisão, da tristeza em contraponto à imensidão, à liberdade e à alegria da beira mar. Seu olhar educado $[. .$. tem que lidar agora com as imagens duras e enfumaçadas que a realidade da vida lisboeta lhe traz (ALBUQUERQUE JUNIOR, 2015, p. 24).

Quanto ao ato de nomear, também presente no poema em questão, percebe-se que é algo recorrente na obra andresiana, porque Albuquerque Junior (2015) o menciona mesmo em outro contexto:
A poesia de Sophia de Mello Breyner Andresen nasce desse desejo de nomear, de dizer, de fazer caber nas palavras, de tornar em palavras a grandeza das coisas, da natureza, do universo, a verdade mais íntima e precisa de suas formas e, ao mesmo tempo, nasce desse desejo de fusão, de retorno, de dissolução no interior da natu- reza, do universo (ALBUQUERQUE JUNIOR, 2015, p. 17).

Outras diferentes interpretações conferidas ao poema Lisboa podem ser lidas abaixo, conforme demonstrou o pesquisador Rodrigo Corrêa Martins Machado (2018):

De um lado, Virgínia Boechat (2004: 12) acredita que [o livro] Navegações segue um itinerário com ênfase na descoberta, no primeiro olhar sobre novos povos e mares, voltando-se também ao olhar dos que refizeram o caminho da viagem. Essa estudiosa ainda destaca que "Sophia segue o itinerário das grandes navegações, numa viagem textual que prima pela beleza e pelo espanto, com raízes, referências e surpresas" (BOECHAT, 2004: 13). Logo, ela sugere que Lisboa é o ponto de partida de uma viagem expansionista de um viajante que "escolhe e capta a impermanência das coisas" [...]. De outro lado, Luis Maffei (2012: 111) advoga para o poema "Lisboa" uma indicação de um sujeito que, vindo do sul, se encontra em uma situação semelhante à do regressado após a descolonização portuguesa na África, "que não é, ressalto, um Ulisses glorioso em sua marca" (MACHADO, 2018, p. 85).

O pesquisador propõe, então, a sua própria alternativa de interpretação para o poema Lisboa:

Após haver uma consciência plena de que o país estava imerso em um caos político, social, econômico (e, por que não, moral?) esse poema pode ser lido [...] enquanto a revelação de um presente soturno [...]. Me deparo com uma urbe representada não mais como um local de onde partem naus desbravadoras de mundos e sonhos e sim [...] um local que reflete o naufrágio de uma civilização, em que vivem os órfãos do passado euforicamente expansionista. [...] O que a poeta efetivamente faz é revelar aos compatriotas a "Lisboa cruelmente construída ao logo da sua própria ausência” [...]. Uma ausência de perspectivas para uma população que vira seus sonhos revolucionários serem destruídos, destroçados pela ganância e mesquinhez humana. Esse poema revela um processo de desvelamento de Lisboa e nele tanto o nomear, como algo genesíaco, quanto o ver, enquanto sentido libertador, são utilizados simultaneamente afim de contribuir para que o sujeito poemático encontre todas as verdades veladas (MACHADO, 2018, p. 85).

Segundo Machado (2018), a própria autora afirma que o tema das navegações não tem apenas relação com o feito marítimo, mas com o olhar e a desocultação. Assim, o pesquisador conclui que:

Este poema é o primeiro [do livro], porque contribui para que o leitor compreenda que há na capital portuguesa um "conivente sorrir de intriga e máscara". Intriga que pode remeter às traições e ciladas que os lusitanos traçaram para si mesmos ao longo de séculos, inclusive no que diz respeito à criação de um imaginário de grandeza que é falaz (MACHADO, 2018, p. 85-86).

A análise de Machado (2018) parece se aproximar mais das interpretações sociopolíticas que vimos anteriormente, que são corroboradas pela 
biografia da poeta, uma vez que ela era engajada politicamente e acreditava numa poesia comprometida. De toda forma, nenhum método de leitura pareceu despropositado ou inconsistente, o que nos leva a concluir que a poesia de Andresen é complexa e abarca múltiplas referências (o passado das navegações, o presente indefinido, as contradições sociais, a mitologia greco-romana). Não parece ser uma poesia com múltiplas chaves de leitura, como em Mallarmé (cada uma fazendo sentido por si só), mas com diferentes possibilidades de interpretação, porque os sentidos se misturam. Isso guarda maior relação com a ilegibilidade das cidades contemporâneas e a emergência de novos campos de estudo que não ditam regras, mas questionam a fixidez de discursos únicos.

Não parece, também, que a poeta pretendia adotar um posicionamento feminista, uma vez que não menciona questões de gênero em seu trabalho ou em entrevistas. É importante salientar, portanto, que para a crítica literária feminista não cabe analisar o posicionamento pessoal da escritora, mas a forma como o seu texto contribui para o debate sobre os espaços das mulheres em diferentes áreas, como as ruas, as cidades e a literatura. Ou seja, a obra de Andresen possibilita pensar diversas questões políticas e sociais que conversam com as questões de gênero, como as desigualdades sociais e as possibilidades de acesso aos espaços. O seu reconhecimento em vida, ao contrário do que aconteceu com Florbela Espanca e com as mulheres do século XIX, foi também uma forma de dar maior visibilidade e reconhecimento à escrita de autoria feminina. Que ela tenha escrito sobre os mais variados temas mostra, ainda, não ser possível enquadrar essa escrita em estereótipos de gênero.

Em conclusão, acredito que os métodos de leitura aqui analisados se somam à primeira aproximação. Algumas leituras semânticas e a análise dos sons se mostraram, inclusive, imprescindíveis para uma melhor compreensão do poema. Ou seja, a primeira aproximação não parece bastar, mas também não é negada pelos outros métodos de leitura. Trata-se, portanto, de um poema que não se esgota facilmen- te - e nesse sentido é um poema ilegível - o que é corroborado pela quantidade de interpretações diferentes já esboçadas por outros/as pesquisadores/as. Assim, este artigo procurou construir um exercício de comparação entre métodos de leitura, de modo a percorrer um caminho, não de apenas compreensão do poema, mas das diferentes formas de enfrentamento das questões da poesia.

\section{Referências}

ALBUQUERQUE JUNIOR, Durval Muniz de. As feridas do tempo: uma história do corpo e da saudade através da poesia de Sophia de Mello Bryner Andresen. Mnemosine revista, Campina Grande, v. 6, n. 2, p. 9-33, abr./jun. 2015. ISSN: 2237.3217. Disponível em: https://s3.amazonaws.com/ academia.edu.documents/38973084/revista_mnemosine_3. pdf?AWSAccessKeyId=AKIAIWOWYYGZ2Y53UL3A\&Expires $=1544470843 \&$ Signature $=$ rYegqGcRpiHoSR8hv6U\%2BHjpLFho\%3D\&response-content-disposition=inline\%3B\%2ofilename\%3DO_educar_no_criar_A_alimentacao_e_a_educ. pdf\#page=10. Acesso em: jan. 2019 .

ANDRESEN, Sophia de Mello Breyner. Lisboa [1983]. In: TAVARES, Maria Andresen Sousa (org.). Sophia de Mello Breyner Andresen no seu tempo: momentos e documentos. Biblioteca Nacional de Portugal, 2011a. Disponível em: http://purl.pt/19841/1/1950/galeria/f27/foto1.html. Acesso em: 6 jan. 2019.

ANDRESEN, Sophia de Mello Breyner. Entrevista a O tempo e o modo [1963]. In: TAVARES, Maria Andresen Sousa (org.). Sophia de Mello Breyner Andresen no seu tempo: momentos e documentos. Biblioteca Nacional de Portugal, 2011b. Disponível em: http://purl.pt/19841/1/galeria/entrevistas/01.html. Acesso em: 6 jan. 2019.

ANDRESEN, Sophia de Mello Breyner. Arte poética III [1964]. In: TAVARES, Maria Andresen Sousa (org.). Sophia de Mello Breyner Andresen no seu tempo: momentos e documentos. Biblioteca Nacional de Portugal, 2011c. Disponível em: http://purl.pt/19841/1/galeria/artes-poeticas/arte-poetica-iii.html. Acesso em: 7 jan. 2019.

ANDRESEN, Sophia de Mello Breyner. Entrevista a Maria Armanda Passos [1982]. In: TAVARES, Maria Andresen Sousa (org.). Sophia de Mello Breyner Andresen no seu tempo: momentos e documentos. Biblioteca Nacional de Portugal, 2011d. Disponível em: http://purl.pt/19841/1/galeria/entrevistas/f1/pag2.html. Acesso em: 6 jan. 2019.

ARAGÃO, Eloisa. Sophia de Mello Breyner Andresen: vida militante. In: ENCONTRO ESTADUAL DE HISTÓRIA DA ANPUH-SP, 22., 2014, Santos. Anais [...] São Paulo: ANPUH, 2014.

BEST GUIDE. Breve história da Lisboa boémia. Disponível em: https://www.bestguide.pt/lisboa/breve-historia-da-lisboa-boemia/. Acesso em: 6 jan. 2019. 
DALCASTAGNÈ, Regina. Sombras da cidade: o espaço na narrativa brasileira contemporânea. Revista Estudos de literatura brasileira contemporânea, Brasília, n. 21, p. 33-53, jan./jul. 2003. Disponível em: http://www.gelbc.com.br/ pdf_revista/2102.pdf. Acesso em: ago. 2016.

ESPANCA, Florbela. Sonetos completos de Florbela Espanca. In: BATELLI, Guido (org.). Lisboa: Editora Amargo, 2013. Disponível em: https://www.luso-livros.net/Livro/sonetos-completos-de-florbela-espanca/. Acesso em: 10 nov. 2018.

FERNANDES, Maria Lúcia O. O mito e a condição humana na obra poética de Sophia de Mello Breyner Andresen. Revista Texto Poético, [s. l.], v. 16, p. 93-122, 2014. ISSN: 1808-5385. Disponível em: http://revistatextopoetico.com.br/index. php/rtp/article/download/209/232. Acesso em: jan. 2019.

FONSECA, Aleilton. As cidades "ilegíveis" e a leitura dos poetas contemporâneos. Sitientibus, Feira de Santana, n. 40, p. 59-68, jan./jun. 2009.

MACHADO, Rodrigo C. M. Navegações ou a descoberta de si. Scripta, Belo Horizonte, v. 22, n. 44, p. 81-92, 2018. Disponível em: https://dialnet.unirioja.es/descarga/articulo/6471655.pdf. Acesso em: jan. 2019. https://doi.or$\mathrm{g} / 10.5752 /$ P.2358-3428.2018v22n44p81

MATOS, Licia R. O.; FARIA, Ângela B. C. O mito de Ulisses e a história lusitana nas mãos de Teolinda Gersão. In: ENCONTRO ABRALIC,15., 2016, Rio de Janeiro. Anais eletrônicos [...] Rio de janeiro: ABRALIC, 2016, p. 676-685. ISSN: 2317-157X. Disponível em: http://www.abralic.org.br/ anais/arquivos/2016_1490918496.pdf. Acesso em: 6 jan. 2019.

PESSOA, Fernando. Mensagem. 1934. Disponível em:

http://www.dominiopublico.gov.br/download/texto/ peo0o004.pdf.

RANCIÈRE, Jacques. Mallarmé: la política de la sirena. Tradução de Cristóbal Durán, Verónica González e Carolina Matamala. Adrogué: LOM, 2015.

SARAMAGO, José. O que farei com este livro? São Paulo: Companhia das Letras, 1998.

WOOLF, Virginia. Um teto todo seu. Tradução de Vera Ribeiro. Rio de Janeiro: Nova Fronteira, 1985.

Recebido em: 17/07/2019.

Aprovado em: 21/10/2019.

\section{Endereço de correspondência:}

Campus Trindade da Universidade Federal de Santa Catarina, Programa de Pós-Graduação em Literatura, Centro de Comunicação e Expressão, Bloco B, sala 329. R. Eng. Agronômico Andrei Cristian Ferreira, s/n - Trindade, Florianópolis - SC, 88040-900. 